\title{
Design for social innovation between university and the broader society: a mutual learning process
}

\author{
Carla Cipolla ${ }^{1, a}$, Bibiana Serpa ${ }^{2}$ and Rita Afonso ${ }^{3}$ \\ 12 Universidade Federal do Rio de Janeiro - UFRJ, Coppe \\ ${ }^{3}$ Universidade Federal do Rio de Janeiro- UFRJ, FACC
}

\begin{abstract}
How to encourage university-community engagement with local communities and disadvantaged groups? This is one of the main questions of the project LASIN - Latin American Social Innovation Network. Specifically, one of the main activities of LASIN is to design and run what are called SISU - Social Innovation Support Units, i.e., units dedicated to support the promotion of social innovation processes between university community members and external actors. Universities are privileged contexts for the experimentation of creative projects in social innovation if the focus is placed on fostering the interaction between internal and external actors, which can be significantly empowered by design practices. The specific objective of this paper is to describe a model for the SISU operation together with principles based on the design approach to social innovation. The recognition of the importance of the design in the promotion of social innovation has been particularly highlighted through the activities of DESIS (Design for Social Innovation Network). Design is also acknowledged through manuals and toolkits (not necessarily developed in design schools) that use tools and methodologies that clearly refer to design approaches. The main research question of this study is: how can design for social innovation promote social innovation at the intersection of the university and the wider society? To answer this question, this study was developed using a research through design approach and applies the SISU under development for the UFRJ - Federal University of Rio de Janeiro as a reference, which includes a consideration of the Brazilian policies (and their qualitative framework) regarding the relationship between university and the rest of society.
\end{abstract}

Keywords. Design, Social Innovation, Latin America, Outreach projects.

\section{Introduction}

How to encourage university-community engagement with local communities and disadvantaged groups? This is one of the main questions of the project LASIN Latin American Social Innovation Network, currently being developed by a consortium of European and LatinAmerican universities, whose activities form the background framework of this study.

Specifically, one of the main activities of LASIN is to design and run what are called SISU - Social Innovation Support Units, i.e., units dedicated to support the promotion of social innovation processes between university community members and external actors with the aim to "contribute to sustainable and inclusive socioeconomic growth in Latin America through intercultural curricular and extracurricular activities for supporting social innovation as a means to promote social cohesion, equity, proper geographical balance and diversity" (Anderson, 2014).

The specific objective of this paper is to describe the model for the SISU operation together with principles based on the design approach to social innovation. The

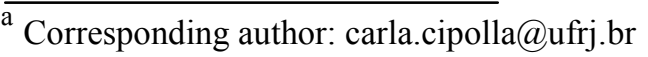

main research question of this study is: how can design for social innovation promote social innovation at the intersection of the university and the wider society? To answer this question, this study was developed using a research through design approach (Mullaney, 2016) and applies the SISU under development for the UFRJ Federal University of Rio de Janeiro as a reference, which includes a consideration of the Brazilian policies (and their qualitative framework) regarding the relationship between university and the rest of society.

Universities are privileged contexts for the experimentation of creative projects in social innovation if the focus is placed on fostering the interaction between internal and external actors, which can be significantly empowered by design practices (Manzini, 2015). The recognition of the importance of the design in the promotion of social innovation has been particularly highlighted through the activities of DESIS (Design for Social Innovation Network), which comprises more than forty Labs based in design schools all over the world. Design is also acknowledged through manuals and toolkits (not necessarily developed in design schools) that use tools and methodologies that clearly refer to 
design approaches (Murray et al., 2010; Corubolo and Meroni, 2015).

However, interactions between university and external actors can be problematic, so that much of the knowledge produced within the university remains in this environment or, due to the lack of effective mediation, the potential for solving social problems promoted by such knowledge is ignored by external communities and groups.

However, the development of outreach projects has been recognized as an important way to foster the interaction between university and the broader society in the Brazilian context. It was defined in 2012 at the National Meeting of FORPROEX (the Forum that gather all ProRectors for Outreach Projects) in what was called a National Plan for Outreach Projects, which states that outreach projects "go[es] beyond its traditional understanding of dissemination of knowledge (courses, conferences, seminars), provision of services (assistance, advice and consultancy) and cultural diffusion (realization of events or artistic and cultural products)" to point out a definition of university in which the relation with external actors is "regarded as oxygenation necessary for academic life" (FORPROEX, 2012). Methodological framework

There are studies that refer to the interaction between universities and the wider society (Greenwood and Levin, 2003), either in the transformation of the society or in its reproduction (Brennan et al., 2004). This study was framed from a design perspective and, to answer the research questions, it was developed as research through design (Mullaney, 2016) in which "the researcher develops a design process as a method to investigate his/her research object" (ibid., p.68). From that, new knowledge is created through the creation of a design artifact. Therefore, the development of a Social Innovation Support Unit at UFRJ was the way to achieve its research objectives.

In the first phase (analysis), the following activities were developed: (1) a theoretical review to understand the concepts of social innovation and design for social innovation to define the theoretical framework and principles of the SISU. The Brazilian policies (and their qualitative framework) regarding the relationship between university and the rest of society were also analysed.

The second phase (synthesis), included: (1) analysis of how social innovation is considered and being developed in other higher education institutions (HEI)around the world. This analysis was looking for different kinds of institutional and organizational arrangements to inspire the definition of the SISU at UFRJ and its specific characteristics in the sector; (2) a focus group with representatives from different sectors of the university (professors, students, technicians)in which qualitative data on expectations, preferences and beliefs about the SISU were raised; (3) semi-structured interview with an actor from outside the university (representative of a Non-Governmental Organization - NGO); (4) the design of the SISU to gather all the collected information. For the design phase, the Business Model Canvas - BMC tool (Osterwalder and Pigneur, 2010) was used, as it allows the SISU model developed for UFRJ to be easily presented in a visual way.

\section{The SISU's theoretical framework and principles}

This section presents the results of the theoretical review on which the key definitions of the SISU were based.

\subsection{Social innovation and design}

The term 'social innovation' is used here with different meanings in five main topics: processes of social change and societal transformation (Young, 2011; Handerson, 2013; Cajaíba-Santana, 2014); business strategies and organizational management (Drucker, 1987; Altuna et al., 2015; Herrera, 2015); social entrepreneurship (Cunha et al., 2015); new products and services (Gershuny, 1982; Mulgan et al., 2007; Phills et al., 2008); and governance and capacity building (Garcia et al., 2016). Moreover, social innovations are also related to specific areas and disciplines, such as sustainable production and consumption (Manzini, 2002; Jaeger-Erben et al., 2015); education (Benneworth and Cunha, 2015); psychology (Bulut et al., 2013) and design (Morelli, 2007). Thus, there are many definitions of social innovation, each best suited to serve the purposes of these various topical and research concerns.

An extensive critical review of the definitions can be found in Cajaíba-Santana (2014). The author emphasizes that "what underlies the path of social innovation is not a social problem to be solved, but the social change it brings about", which includes the creation of new ideas that propose "new alternatives and new social practices for social groups" (p. 44). According to Franz et al. (2012, p.4), the most distinctive feature of social innovation is a change in "the way people decide, act and behave, alone or together". Moulaert (2013, p.2) defines social innovation as "innovation in social relations, structures of governance, greater collective empowerment and so on". Haxeltine et al. (2015) define Transformative Social Innovation as "a change in social relations, involving new ways of doing, organizing, framing and/or knowing, which challenges, alters and/or replaces dominant institutions/structures in a specific social context" and a social innovation initiative (SIinitiative) is defined as a "collective of actors that (aims to) work on ideas, objects and/or activities that are socially innovative" (ibid., p 18); Cipolla and Manzini (2009) highlighted the role of interpersonal relational qualities in social innovation processes.

Among all the social innovation definitions analysed, this study considers the ones mentioned in the previous 
paragraph to compose a specific definition to guide the development of the SISU at UFRJ:

Social innovation is a change that manifests new ways of doing, organizing, framing and/or knowing, that are based on new interpersonal relational patterns between participants and greater collective empowerment in the face of social demands and challenges with the aim to foster a systemic change. This change can be intermediated by products or services, but social innovation happens throughout the process. That said, it is recognized that social innovation processes can be facilitated and supported by projects, but these should be welcomed and their characteristics jointly developed by stakeholders, with commonly recognized benefits being produced throughout the project development.

This definition includes reference to co-design processes as a key element of design for social innovation (Manzini, 2015) .Manzini (2014) also recognizes that design for social innovation corresponds to a set of activities in which the designer contributes to the process of co-design for social change. With the term 'codesign', the author understands that design for social innovation occurs when different actors, both specialists and non-specialists, are able to interact in a way that considers diverse environments and encompasses several competences (Sanders and Stappers, 2008).

Social change is understood by as "all processes of change that contribute to sustainability, not only the reduction of environmental impact, but the regeneration of common goods and the reconstitution of the social fabric" (Manzini, 2014, p. 65).

There are many tools that rely on design to promote social innovation. An example of how this approach could work comes from the DIY (Development Impact and You), a platform built by NESTA (Murray, 2010), in which a set of tools was developed, "specially designed for practitioners to dive straight into action. Yet the tools presented here are grounded in existing theories and practices of innovation, design, and business development." (Development Impact and You, 2017). This is a useful framework for understanding "how to put ideas to work, and focusing on the different methods, and different mindset, needed at each stage" (Ibid). Here, design expertise is related to others (business, anthropology, etc.) to empower social innovation processes.

Another example comes from a member of DESIS Network (Design for Social Innovation and Sustainability). The DESIS Lab based at Politecnico di Milano developed an action format of design for social innovation, the 'Social Innovation Journey', structured on a non-linear sequence of steps and actions that progressively engage a community and help it to set up and prototype a social innovation activity (Meroni et al., 2013). The journey is designed to develop social innovation ideas from a very early stage.

\subsection{Universities and their outreach activities in the Brazilian context}

The end of the dictatorship period enabled Brazilian universities to rethink their role and interactions with other sectors and actors in society. The relationships between the practices of Teaching, Research and Outreach Projects (the three pillars to be developed by universities) were redefined, and a non-assistencialist view (Freire 1970, 1978) of the Outreach Projects was put in place.

The importance of outreach projects for Brazil's development was endorsed by the government, and defined by a specific law and a national plan ${ }^{\mathrm{a}}$.Outreach activities are understood as interdisciplinary processes, indissociable from teaching and research, and based on educational, cultural, scientific and political principles oriented to promote the transformative interaction between university and other sectors of society (FORPROEX, 2007, Nogueira, 2000).

Rocha (2006) defines Outreach Projects as those with active involvement of social movements, local communities, organized social groups - formal or informal - in facing problems whose solutions may be rooted in the results of research or the experience of previous outreach projects. Regarding this definition, the author still suggests that the scientific interests of researchers and the production of scientific knowledge are closely linked to the satisfaction of needs and interests of social groups deprived of power. Without the interaction allowed by Outreach Projects, the university runs the risk of being isolated, detached from the most pressing social problems and incapable of offering society and governments the knowledge, technological innovations and professional skills that sustainable development requires.

To concretize this renewed link between university and the wider society, the Outreach Projects should aim to provide support in solving the problems of social exclusion and social discrimination (FORPROEX, 2012).

Within the framework of the previous definitions of social innovation and design for social innovation- on which co-design (Manzini, 2014), innovation in social relations and collective empowerment (Moulaert, 2013; Cipolla and Manzini, 2009) are focussed -the SISU in

\footnotetext{
${ }^{a}$ The Law of Directives and Principles for National Education (Law No. 9,394), establishes the Outreach activities as one of the purposes of the University and settles the possibility for financial support from the Government, through scholarships and grants (Articles 44, 52, 53 and 77). Soon after the National Plan for Outreach Projects from 1998, elaborated and approved by FORPROEX, increased the scope of the outreach activity and valued this practice in the university. In the same logic, the National Education Plan (re) established the universities' responsibility in their teaching, research and outreach functions in the initial and continued qualification of basic education professionals and set up that "at least $10 \%$ of the total credits required to get under graduation degrees in Brazil will be reserved for the students' activities in outreach actions" (FORPROEX, 2012).
} 
the UFRJ aims to sustain the groups and communities excluded and discriminated against as protagonists of their own processes of change, which are to be done together with the university community, in a mutual learning process. The SISU is focused not only on these groups and communities, but embraces and supports all kinds of actors and their respective challenges, ideas and solutions that could be framed within the definition of social innovation as stated in this study.

\section{The SISU's institutional framework and operation}

\subsection{Case analysis and SISU's specific features}

The analysis was focused on understanding the characteristics of units situated in higher education institutions(HEI) that have stated their main aim as supporting projects with social purposes. Among the cases collected, the definition of social innovation varied and some did not correspond with the one adopted in this study. This list is not exhaustive, but was built to identify the main typologies of institutional affiliation and operational models. The following typologies were found (examples for each typology are listed in Table 1).
- SISU placed at a high management level within the HEI:

supports myriad projects inside the HEI, and works as an enabling unit for outreach projects, working through calls for projects and providing bursaries;

- $\quad$ SISU inside specific departments in the HEI: is formalized as a research centre or a lab coordinated by a professor, a group of professors or other university staff;

- SISU as an incubator: is formalized as an incubator to support social projects and enterprises;

- $\quad$ SISU as a specific project: is constituted as a specific project that exist to foster social projects;

- $\quad$ SISU as a combination of different previous strategies.

Table 1: Examples of SISU identified

\begin{tabular}{|c|c|}
\hline $\begin{array}{l}\text { Typology of institutional } \\
\text { affiliation and operation }\end{array}$ & Example(s) \\
\hline $\begin{array}{l}\text { SISU placed at a high management } \\
\text { level within the HEI }\end{array}$ & UFRJ Pro-Rectorate for Outreach projects(http://extensao.ufrj.br/) \\
\hline $\begin{array}{l}\text { SISU inside specific departments in } \\
\text { the HEI }\end{array}$ & $\begin{array}{l}\text { LTDS Laboratory of Technology and Social Development } \\
\text { (http://www.ltds.ufrj.br) } \\
\text { DESIS Lab Politecnico di Milano (http://www.desis.polimi.it/) } \\
\text { Center for Social Design, MICA (http://www.micasocialdesign.com/) } \\
\text { Stanford Center for Social Innovation (http://www.gsb.stanford.edu/faculty- } \\
\text { research/centers-initiatives/csi) }\end{array}$ \\
\hline SISU as an incubator & Centro de Inovación y Emprendimentos(http://cie.ort.edu.uy/) \\
\hline SISU as a specific project & $\begin{array}{l}\text { Expedition Münsterland (http://www.uni-muenster.de/Expedition- } \\
\text { Muensterland/projekt/index.html) } \\
\text { Bertha Center for Social Innovation - University of Cape Town - } \\
\text { (http://www.gsb.uct.ac.za/s.asp?p=178) }\end{array}$ \\
\hline $\begin{array}{l}\text { SISU as a combination of different } \\
\text { previous strategies }\end{array}$ & $\begin{array}{l}\text { The Waterloo Institute for Social Innovation and resilience (WISIR) - } \\
\text { (http://sig.uwaterloo.ca/) }\end{array}$ \\
\hline
\end{tabular}


Based on this analysis, and comparing it with the institutional and legal framework in Brazil, it was identified that the SISU at UFRJ operates more effectively if recognized as an Outreach Project ("SISU as a specific project") by the UFRJ Pro-Rectorate for Outreach projects. The conceptualization and development of the SISU in the UFRJ took advantage of the benefits provided by Brazil's law and policies that govern the development of outreach projects, specifically:

$-10 \%$ of the total credits required to get undergraduate degrees in Brazil will be reserved for the students' activities in outreach actions;

-the development, participation and coordination of outreach projects is required for professors to advance their academic careers;

-the possibility for financial support from the Government, through scholarships and grants.

This means that academic credits can be provided to students involved in the SISU's activities (they could also be awarded scholarships). It can also attract professors interested in advancing their academic careers to work on an Outreach Project.

\subsection{Feedback from representatives in and outside the university}

The university focus group revealed that it is feasible for the SISU to be operated as an outreach project. The definition of social innovation adopted in this study was confirmed (even if not with the same specific terms and paragraphs). The motivation for students to engage in the SISU was discussed (students can choose from a wide portfolio of different outreach projects in the university to get their credits). The support for leadership of students in developing outreach activities, with professors and technicians acting mainly as tutors, was considered an important motivational aspect. Students were also motivated to develop their own projects and find resources in the university to get them developed. Students also stressed the importance for them to have information about and access to different resources in the university; this was mainly knowledge and tools dispersed around different research groups and labs, that was not easily accessed or known about. It was reported that a project is being developed by students in UFRJ to answer this demand. It was confirmed that the SISU would also support this project being one of the resources available.

The semi-structured interview with an external actor (representative of an NGO working to protect animals) revealed his interest in getting support from the SISU to develop its core activity, mainly through gaining access to the university's expertise and human resources. It was therefore noted that one of the key activities of the SISU should be to find common interests between students (supported and guided by professors and technicians) and external actors, which could motivate both to engage in the development of common projects. Jointly, they can promote social change by performing a mutual learning process in which existing or new social innovations are improved or developed.

\subsection{The UFRJ SISU model}

To synthetize information collected in the first and second phases of this study, a Business Model Canvas BMC (Osterwalder and Pigneur, 2010) was built. Although the BMC was recognized as a useful tool, its specific features were adapted to be used in this study: it included the substitution of the term "customer" for "user" and the insertion of a cell called "Non-monetary Resources", to indicate that the SISU is sustained also by internal resources of the university, which do not include payments to people involved.

Table 2 offers a visual presentation of the different aspects of the SISU. Two main aspects guided the description of the SISU using the BMC tool ${ }^{\mathrm{b}}$ : the value proposition of the SISU is stated based on: (1) the definition of the social innovation established in this study; (2) the qualitative characteristics of the outreach projects recognized by the university. Other cells were filled with specific operational aspects that support this value proposition (key partners, key activities, key resources, relationship between users and the SISU, user segments and channels through which the value proposition is delivered to users.

The SISU is defined as an interdisciplinary and interinstitutional outreach project managed by the Graduate Programme of Production Engineering (usually known as Industrial Engineering) at Coppe/UFRJ, which reports directly to a high management level within the HEI, the UFRJ's Pro-Rectorate for Outreach Projects; it is coordinated by professors programme, where the SISU is also physically located.

It gathers professors from different departments and courses and, in this, the SISU provides the expertise of the whole university to external actors. It encompasses entrepreneurship, innovation, management, marketing and design, including service and product development ${ }^{\mathrm{c}}$.

\footnotetext{
$\mathrm{b}$ The Business Model Canvas used has been adapted to insert a cell called «Non-Monetary resources »

${ }^{\mathrm{c}}$ Specifically, considering the expertise of each professor involved the SISU can provide support in the following fields: Design thinking; Service and Product Design; Strategic Design; Social Business Models; Social Marketing; Local Development; Cultural Production (including video production and new media); Business/Organizational Management; Hospitality and Gastronomy; Community-based Tourism; Entrepreneurship management and support.
} 
The SISU process and projects include qualitative issues, such the adoption of participatory and co-design processes and new patterns of interpersonal relations. The value of the knowledge brought by the users and stakeholders is recognized and is an important aspect of the SISU operation.

In terms of physical space, usually in the UFRJ, professors have specific spaces (called labs) to develop their activities. The SISU is designed as part of a "multilab" approach. The spaces are designed to host different labs and activities developed by the professors involved, including the SISU itself. This allows the physical space of the SISU to be used as a meeting place, hosting different activities led by the professors involved.

Table 2: SISU model (Business Model Canvas adapted)

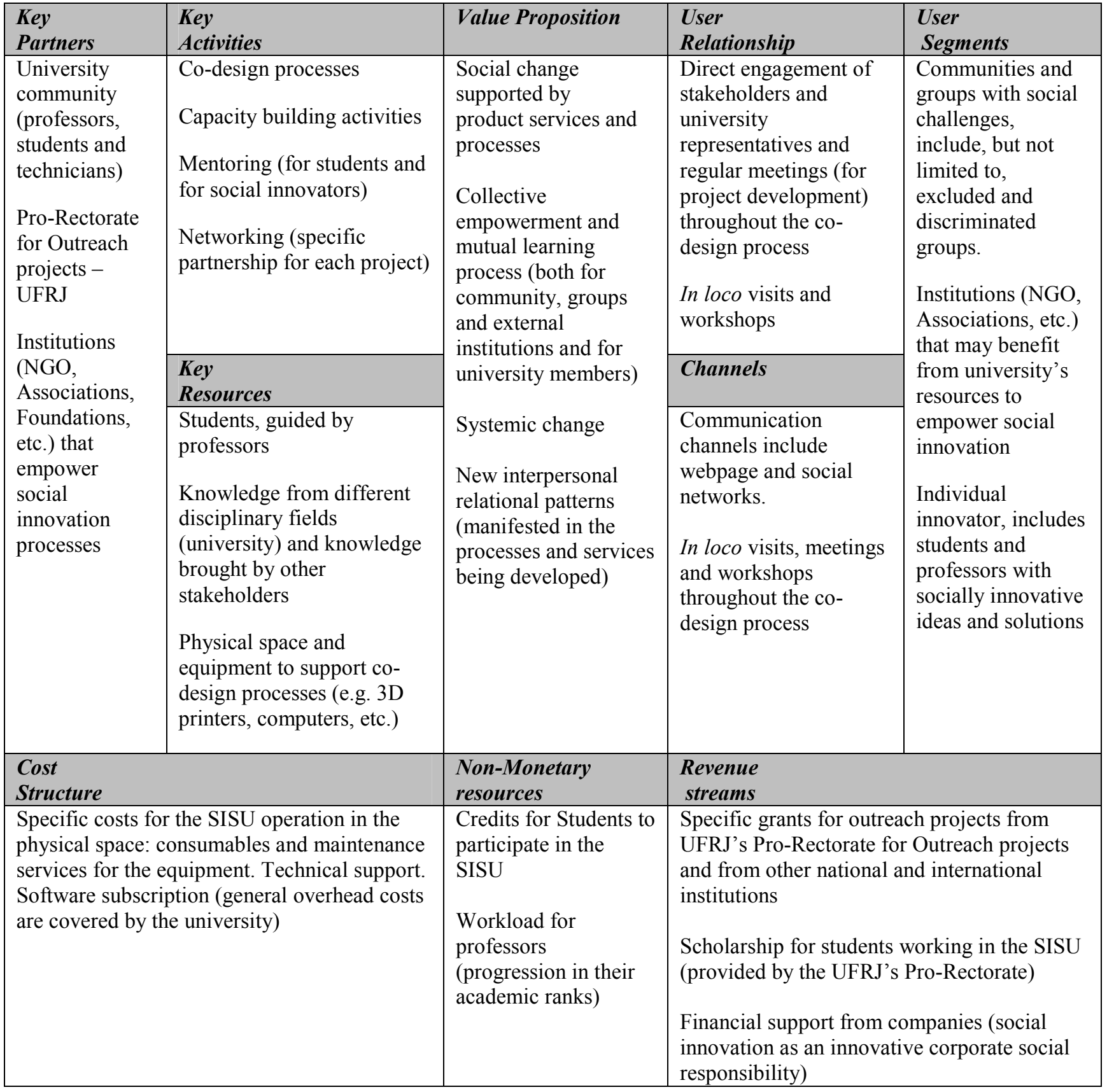


The SISU will also be an identifiable location for people looking for support for social innovation and entrepreneurship. The physical space will include specific features to host the SISU activities (e.g., making and workshop sessions related to co-design processes). Many activities can be held in loco, where groups and communities are situated, and not only in the SISU room in the university.

The SISU relies on existing methods and tools to empower social innovation processes, such as DIY (Murray et al.,2010) and the Social Innovation Journey (Corubolo and Meroni, 2015), which include design tools and principles. The tools and methods provided by the different professors and their diverse disciplinary fields will be also included. This has the potential to generate new tools and methods, customized specifically for the SISU operation.

This paper describes the current stage of development of the SISU. One of the issues under development is the definition of criteria to evaluate the impact of the SISU processes.

\section{Conclusions: the role of design between university and the broader society}

The main research question of this study is: how can design for social innovation promote social innovation at the intersection of the university and the wider society? The development of the SISU in the UFRJ raised interesting elements consider in proposing answers.

The intersection of multiple disciplines in the promotion of social innovation has been highlighted in the literature review undertaken for this study. Therefore, the SISU does not embrace only design theory and practices in its processes; design experts have a role in the interaction with other disciplines. Expert designers in the SISU are invited to work with communities, groups and a variety of stakeholders. Here, is useful to remember the distinction proposed by Manzini (2015) between diffuse design and expert design: "In a connected world design processes tend to be increasingly distributed among numerous actors who differ in culture, motivation, and professional development (...) traditional design knowledge, accumulated within the implicit knowledge of design experts, is no longer enough: too many subjects are involved and too many of them are not in the same place" (pp.38-39). The recognition of a diffuse design knowledge is also part of the SISU, when it attained the value of the knowledge brought by the external actors of the university.

Consequently, the SISU, positioned at the intersection between the university and the rest of society acts in a dual mode:
1) as a 'hub' on which the knowledge and creativity inside and outside the university (including a diffuse design knowledge) can interact and produce new ideas, expressed in new social innovations.

2) promotes a mutual learning process in which the representatives of these different knowledges (university and broader society) can learn with each other.

This could generate collective empowerment for all parties involved. Expert designers can support these processes by providing their problem-solving and sensemaking skills (Manzini, 2015).

In its almost ten years of activity, DESIS Network and the experiments of the DESIS Labs are a precious resource to be analysed by those interested in how design can promote social innovation from university to the wider society and vice-versa. The researchers who undertook this study are members of a DESIS Lab. The development of the SISU in the UFRJ is an opportunity for the local DESIS Lab to develop its activities with a renewed relationship with other disciplinary sectors in the university. Specifically, by coordinating the development of the SISU at UFRJ, it is in a privileged condition to increase the understanding about the application of design theory and practices (expert or diffused) to support socially innovative processes and results.

\section{References}

ALTUNA, N., CONTRI, A.M., DELL'ERA, C., FRATTINI, F. and MACCARRONE, P. 2015. Managing Social Innovation in for- profit organizations: the case of Intesa Sanpaolo. European Journal of Innovation Management, 18(2), 258-280.

ANDERSON, M. 2014. Latin American Social Innovation Network (LASIN) - project description. [online] URL: http://www.lasin-eu.org. Accessed: 25 January 2017.

BENNEWORTH, P. AND CUNHA, J. 2015. Universities' contributions to social innovation: refletions in theory \& practice. European Journal of Innovation Management, 18 (4), 508-527.

BRENNAN, J., KING, R. AND LEBEAU, Y. 2004. The Role of Universities in the Transformation of Societies: An International Research Project. Synthesis Report, Association of Commonwealth Universities and Open University. 
BULUT, C, EREN, H. AND HALAC, D. S. 2013. Social Innovation and Psychometric Analysis. ProcediaSocial and Behvioral Sciences, 82 (3), 122-130.

CAJAÍBA-SANTANA, G. 2014. Social innovation: Moving the field forward. A conceptual framework. Technological Forecasting \& Social Change 82 (2014) $42-51$.

CIPOLLA, C. AND MANZINI, E. 2009. Relational Services. Knowledge, Technology \& Policy, 22 (1), 4550 .

CORUBOLO, M. AND MERONI, A. 2015. A Journey into Social Innovation Incubation. The TRANSITION Project. In: Collina, L., Galluzzo, L., \& Meroni, A., (Eds). Proceedings of CUMULUS Spring Conference 2015 - The Virtuous Circle Design Culture and Experimentation, Politecnico di Milano 3-7 June, Milano, Italy.

CUNHA, J., BENNEWORTH, P. AND OLIVEIRA, P. 2015. Social Entrepreneurship and social innovation: A conceptual distinction. In: Farinha, L.M.C., Ferreira, J.J.M, Smith, H. L. and Bagchi-Sen, S. (Eds.) Handbook of Research on Global Competitive Advantage through Innovation and Entrepreneurship. Hershey, Pennsylvania: IGI Global, 616-639.

DIY. Development Impact and You. 2017. "Background". [online] URL: http://diytoolkit.org/background/ Accessed: 24 January 2017.

ANDERSON, M. 2014. Latin American Social Innovation Network (LASIN) - project description. [online] URL: http://www.lasin-eu.org. Accessed: 25 January 2017.

DRUCKER, P. F. 1987. Social Innovation Management's new dimension. Long Range Planning, $20(6), 29-34$.

FRANZ, H. W., J. HOCHGERNER, AND J. HOWALDT. 2012. Challenge Social Innovation: Potentials for Business, Social Entrepreneurship, Welfare and Civil Society. Springer.

FREIRE, P. 1970. Pedagogy of the Oppressed. Boston: Bergin and Garvey.

FREIRE, P. 1978. Education for Critical Consciousness. New York: Seabury Press.
FORPROEX - Fórum de Pró-Reitores de Extensão das Universidades Públicas Brasileiras. 2007. Extensão Universitária: organização e sistematização. Belo Horizonte: Coopmed.

FORPROEX - Fórum de Pró-Reitores de Extensão das Universidades Públicas Brasileiras. 2012. Política Nacional de Extensão Universitária. Manaus: Universidade Federal do Amazonas.

GARCÍA, M, EIZAGUIRRE, S. AND PRADEL, M. 2015. Social Innovation and Creativity in Cities: a socially inclusive governance approach in two peripheral spaces in Barcelona. City, Culture and Society, 6 (4), 93-100.

GERSHUNY, J. I. 1982. Social Innovation - Change in the mode of provision of services. Futures, 14 (6), 496516.

GREENWOOD, D.J, AND LEVIN, M. 2003. Reconstructing the relationships between Universities and society through action research. In: Lincoln, Y. and Denzin, N. K. (Eds). The landscape of qualitative research: theories and issues, London: Sage, 131-166.

HANDERSON, H. 1993. Social Innovation and Citizens movements. Futures 25 (3), 322-338

HAXELTINE, A., R. KEMP, A. DUMITRU, F. AVELINO, B. PEL. B., AND J. WITTMAYER. 2015. TRANSIT WP3 deliverable D3.2 - A first prototype of TSI theory. TRANSIT: EU SSH.2013.3.2-1 Grant agreement no 613169 [online] URL: http://www.transitsocialinnovation.eu/resourcehub/transit-wp3-delverable-d32---a-first-prototype-oftsi-theory Accessed: 20 January 2017.

HERRERA, M. E. B. 2015. Creating competitive advantage by institucionalizing corporate social innovation. Journal of Business Research, 68 (7), 1468-1474.

JAEGER,-ERBEN, M. RUCHERT-JONH, J. AND SCHAFER, M. 2015. Sustainable consumption through social innovation: a typology of innovation for sustainable consumption practices. Journal of Cleaner Production, 108 (1), 784-798.

MANZINI, E. 2002. Context-based wellbeing and the concept of regenerative solution. A conceptual framework for scenario building and sustainable solutions development. The Journal of Sustainable Product Design, 2(3), 141-148 
MANZINI, E. 2014. Making things happen: social innovation and design. Design Issues, 30(1), 57-66.

MANZINI, E. 2015. Design when everybody designs An introduction to design for social innovation. Cambridge, Londres: MIT Press.

MERONI, A., FASSI, D., \& SIMEONE, G. (2013). Design for social innovation as a form of designing activism. An action format. In.: NESTA (Eds.), Social Frontiers, The next edge of social innovation research. London: NESTA, 2-13.

MORELLI, N. 2007. Social Innovation and New Industrial Contexts: Can Designers "Industrialize" Socially Responsible Solutions? Design Issues, 23 (4), 3-21.

MOULAERt, F. 2013. The International Handbook on Social Innovation: Collective Action, Social Learning and Transdisciplinary Research. Edward Elgar, Cheltenham, UK.

MULGAN, G., TUCKER, S., ALI, R. SANDERS B. 2007. Social innovation: what it is, why it matters and how it can be accelerated, Working Paper. London: The Young Foundation.

MULLANEY, T. 2016. Thinking beyond the cure: A constructive design research investigation into the patient experience of radiotherapy. Dissertation for the degree of Doctor of Philosophy in Industrial Design. Umeå Institute of Design Research Publications, 003.

MURRAY, R.; CAULIER-GRICE, J.; MULGAN, G. 2010. The open book of social innovation. London: The Young Foundation/The Basingstoke Press.

NOGUEIRA, M. D. P. (Ed.). 2010. Extensão Universitária: diretrizes conceituais e políticas. Belo Horizonte: PROEX/UFMG.

OSTERWALDER, A. and PIGNEUR, Y. 2010. Business Model Generation: A Handbook for Visionaries, Game Changers, and Challengers. New Jersey: John Wiley \& Sons, Inc.

PHILLS, J.A., DEIGLMEIER, K., MILLER, D.T. 2008. Rediscovering social innovation, Stanford Social Innovation Review (6), 34-43.

ROCHA, J.C. 2006. A reinvenção solidária e participativa da universidade: um estudo de caso múltiplo sobre rede de extensão universitária no
Brasil. 2006. PhD Thesis. Salvador: Universidade Federal da Bahia (UFBA).

SANDERS, E and STTAPPERS, P. 2008. Co-creation and the new landscapes of Design, Codesign, 4(1), 5-18

YOUNG, H. P. 2011. The dynamics of social innovation. Proceedings of the National Academy of Sciences of the USA, 108 (4), 21825-21291. 